\title{
Comparison of Cardiac Output of Cricket Players on the basis of their Playing Experience
}

\author{
Lokendra Bahadur Kathayat and Ashok Kumar
}

\begin{abstract}
Aims: The purpose of this study was to compare the cardiac output of cricket players before and after step test on the basis of their playing experience. Materials and Methods: There was one hundred fifty $(\mathrm{N}=150)$ trained male cricketers between the ages of 15 and 25 years volunteered for this study. Anthropometric rod, Weighing machine were used. Blood pressure was recorded with a digital sphygmomanometer according to the standardized protocol recommended by World Health Organization. Results: The mean age, height weight and BMI (body mass index) of playing experience Group-1(1to5year) cricketer was $17.19 \pm 2.06$ year, $170.57 \pm 7.67 \mathrm{~cm}, 56.01 \pm 8.99 \mathrm{~kg}$ and $19.19 \pm 2.44 \mathrm{~kg} / \mathrm{m}^{2}$ respectively. The mean age, height weight and BMI (body mass index) of playing experience Group-2(6 to10year) cricketer was $19.50 \pm 3.24$ year, $173.50 \pm 6.46 \mathrm{~cm}, 62.29 \pm 9.20 \mathrm{~kg}$ and $20.64 \pm 2.47 \mathrm{~kg} / \mathrm{m}^{2}$ respectively. The mean age, height weight and BMI (body mass index) of playing experience Group-3(11to15year) cricketer was $24.67 \pm 0.57$ year, $174.00 \pm 8.54 \mathrm{~cm}$, $69.33 \pm 6.02 \mathrm{~kg}$ and $23.08 \pm 3.86 \mathrm{~kg} / \mathrm{m}^{2}$ respectively. Conclusion: It was concluded that the cardiac output showed significant statistical increase represented by values of step test. There was a statistically significant difference in the variance of mean cardiac output (after Queen's step test) of 1 to 5 year, playing experience of 6 to 10 year, playing experience of 11 to 15 year) cricket players.
\end{abstract}

Lokendra Bahadur Kathayat

Assistant Professor

Department of Physical Education

RIMT University Mand iGobindgargh, Punjab, India

Email: lukskathayat@gmail.com

Ashok Kumar

Professor

Department of Sports Science

Punjabi University (Patiala) Punjab, India.

Email: akashokin@gmail.com

\section{Introduction}

Nowadays cricketers endure extreme training to be in highest state of physical fitness. Cardiac output (CO) is the quantity of blood or volume of blood that is pumped by the heart per minute. Cardiac output is a function of heart rate and stroke volume (Hussien et al. 2011). It is the product of stroke volume (SV; the volume of blood ejected from the heart in a single beat) and heart rate (HR; expressed as beats per minute) (Zhang et al. 2011). Heart rate (HR), lowering agent which is very useful (Xing et al. 2016 ; Busseuil et al. 2010). During exercise body may need three or four times that of normal cardiac output, because muscles need more oxygen when body exert. During exercise, your heart typically beats faster so that more blood gets out to the body (Hargreaves \& Spriet 2020). During exercise, changes in cardiac preload, heart rate, and after load synergize to increase workload, which augments energy demand and influences substrate metabolism. Heart's, this increase in workload is sufficient to increase myocardial carbohydrate and fatty acid catabolism (Goodwin and Taegtmeyer 2000). Further evidence showed that workload is sufficient to change 


\section{Journal of Exercise Science \& Physiotherapy Vol.17 No.1 (January to June) 2021 \\ ISSN: 0973-2020 (Print) I2OR Impact Factor =7.005 ISSN: 2454-6089 (Online)}

substrate metabolism of atrial pacing, which increases cardiac work without affecting circulating substrates. Atrial pacing causes the heart to use more fatty acids (Bergman et al. 2009) and it also increases glucose and lactate uptake in proportion to myocardial energy demand (Bergman et al. 2009). Increasing either heart rate or stroke volume increases cardiac output. Most of the strokes are caused by atrial fibrillation (Duning et al. 2011). Cardiac Output in $\mathrm{ml} / \mathrm{min}=$ heart rate (beats/min) $\mathrm{X}$ stroke volume $(\mathrm{ml} / \mathrm{beat})$. An average person has a resting heart rate of 70 beats / minute and a resting stroke volume of $70 \mathrm{ml} /$ beat. The cardiac output for this person at rest is : Cardiac Output $=$ 70 (beats $/ \mathrm{min}) \times 70(\mathrm{ml} /$ beat $)=4900 \mathrm{ml} /$ minute. The difference between maximum and resting $\mathrm{CO}$ is known as the cardiac reserve. It measures the residual capacity of the heart to pump blood (Takahash et al. 2013).During exercise, tidal volume increases as the depth and rate of breathing both become greater. This has the effect of taking more oxygen into the body and removing more carbon dioxide (Kirolos et al. 2019). Cardiac output will continue to increase till the point where a plateau is reached (Adikali et al. 2017). There are very few studies that have been conducted on male cricket players of Punjab to observe the status of haemodynamic variables keeping in view their playing experience.

\section{Materials and Methods}

One hundred fifty $(\mathrm{N}=150)$ Punjabi male cricketers (from different cricket academies situated at Patiala,Punjab) between the age group of 15 to 25 years voluntarily participated in the study. Anthropometric measurements were recorded according to the standard procedure. Blood pressure was recorded with a digital sphygmomanometer according to the standardized protocol recommended by World Health Organization. Blood pressure was measured at rest and after the completion of queens step test. The cardiac output was calculated with the help of standard equations i.e. Cardiac Output $(\mathrm{ml} / \mathrm{min})=$ Heart Rate $($ beats $/ \mathrm{min}) \times$ Stroke Volume $(\mathrm{ml} /$ beat $)$ (Jackson 1955).

\section{Results}

The mean age, height weight and BMI (body mass index) of cricketer of Group-1 (1 to 5 year playing experience) was $17.19 \pm 2.06$ year, $170.57 \pm 7.67 \mathrm{~cm}, 56.01 \pm 8.99 \mathrm{~kg}$ and $19.19 \pm 2.44 \mathrm{~kg} / \mathrm{m}^{2}$ respectively. The mean age, height weight and BMI (body mass index) of cricketer of Group-2 (6 to 10 year playing experience) was $19.50 \pm 3.24$ year, $173.50 \pm 6.46 \mathrm{~cm}, 62.29 \pm 9.20 \mathrm{~kg}$ and $20.64 \pm 2.47$ $\mathrm{kg} / \mathrm{m}^{2}$ respectively. The mean age, height weight and BMI (body mass index) of cricketer of Group3 (11 to 15 year playing experience) was $24.67 \pm 0.57$ year, $174.00 \pm 8.54 \mathrm{~cm}, 69.33 \pm 6.02 \mathrm{~kg}$ and $23.08 \pm 3.86 \mathrm{~kg} / \mathrm{m}^{2}$ respectively (Table1).

Table1. Mean \pm SD of Age, height weight and BMI of Cricket Players

\begin{tabular}{|l|c|c|c|c|c|}
\hline $\begin{array}{l}\text { Player's Playing } \\
\text { Experience }\end{array}$ & $\mathrm{N}$ & $\begin{array}{c}\text { Age, } \\
(\text { year })\end{array}$ & $\begin{array}{c}\text { Height } \\
(\mathrm{cm})\end{array}$ & $\begin{array}{c}\text { Body } \\
\text { weight } \\
(\mathrm{kg})\end{array}$ & $\begin{array}{c}\text { BMI } \\
\left(\mathrm{kg} / \mathrm{m}^{2}\right)\end{array}$ \\
\hline Group-1(1 to 5 year) & 119 & $\mathbf{1 7 . 1 9} \pm 2.06$ & $\mathbf{1 7 0 . 5 7} \pm 7.67$ & $\mathbf{5 6 . 0 1} \pm 8.99$ & $\mathbf{1 9 . 1 9} \pm 2.44$ \\
\hline Group-2(6 to 10 year) & 25 & $\mathbf{1 9 . 5 0} \pm 3.24$ & $\mathbf{1 7 3 . 5 0} \pm 6.46$ & $\mathbf{6 2 . 2 9} \pm 9.20$ & $\mathbf{2 0 . 6 4} \pm 2.47$ \\
\hline Group-3(11 to 15 year) & $\mathbf{3}$ & $\mathbf{2 4 . 6 7 \pm 0 . 5 7}$ & $\mathbf{1 7 4 . 0 0} \pm 8.54$ & $\mathbf{6 9 . 3 3} \pm 6.02$ & $\mathbf{2 3 . 0 8} \pm 3.86$ \\
\hline Total & $\mathbf{1 5 0}$ & $\mathbf{1 7 . 7 7} \pm 2.66$ & $\mathbf{1 7 1 . 1 9} \pm 7.52$ & $\mathbf{5 7 . 4 5} \pm 9.42$ & $\mathbf{1 9 . 5 4} \pm 2.58$ \\
\hline
\end{tabular}

The mean cardiac output (resting) of cricket players of Group-1(1 to 5 year), Group-2(6 to 10 year), and Group-3(11 to 15 year) was $6.26 \pm 1.048(\mathrm{~L} / \mathrm{min}), 6.07 \pm 1.30(\mathrm{~L} / \mathrm{min})$ and $4.89 \pm 0.42(\mathrm{~L} / \mathrm{min})$ respectively. The maximum mean cardiac output at rest $(6.26 \pm 1.048 \mathrm{~L} / \mathrm{min})$ was of Group-1(1 to 5 year). The minimum cardiac output (at rest) $(4.89 \pm 0.42 \mathrm{~L} / \mathrm{min})$ was of Group-3(11 to 15 year) 
(Table 2). The mean cardiac output (after Queen's step test) of cricket players of Group-1(1 to 5 year), Group-2(6 to 10 year), and Group-3(11 to 15 year) was $11.12 \pm 2.02$ (L/min), $10.54 \pm 1.93$ $(\mathrm{L} / \mathrm{min})$ and $10.76 \pm 1.18(\mathrm{~L} / \mathrm{min})$ respectively. The maximum mean cardiac output of cricket players at rest $(11.12 \pm 2.02 \mathrm{~L} / \mathrm{min})$ was of Group-1(1 to 5 year). The minimum cardiac output of cricket players (at rest) $(10.54 \pm 1.93 \mathrm{~L} / \mathrm{min}$ ) was of Group-2 (6 to 10 year) (Table 2). The mean difference in the cardiac output at rest and after queen's step test of group-1 (1 to 5 year) was statistical significant, in other words we can say that there was increased in cardiac output $(4.86 \mathrm{~L} / \mathrm{min})$ after queen's step test of group-1 (1 to 5 year) cricket players (Table 2). The mean difference in the cardiac output at rest and after queen's step test of cricket players of group-2 (6 to 10 year) was statistical significant, in other words we can say that there was increased in cardiac output (4.46 L/min) after queen's step test of group-2 (6 to 10 year) cricket players (Table 2). The mean difference in the cardiac output at rest and after queen's step test of group-3 (11 to 15 year) was statistical significant, in other words we can say that there was increased in cardiac output (5.87 L/min) after queen's step test of group-3 (11 to 15 year) cricket players (Table 2).

Table 2. Comparison of Cardiac output at rest and after Queen's step test of cricket players

\begin{tabular}{|c|c|c|c|c|c|c|c|c|}
\hline \multirow[t]{2}{*}{$\begin{array}{c}\text { Player's } \\
\text { Playing } \\
\text { Experience }\end{array}$} & \multicolumn{3}{|c|}{$\begin{array}{c}\text { Cardiac Output } \\
\text { (at rest) }\end{array}$} & \multicolumn{2}{|c|}{$\begin{array}{l}\text { Cardiac Output } \\
\text { (after Queen's } \\
\text { step test) }\end{array}$} & \multirow[t]{2}{*}{$\begin{array}{c}\text { Mean } \\
\text { difference }\end{array}$} & \multirow[t]{2}{*}{$\mathbf{t}$} & \multirow[t]{2}{*}{$\begin{array}{l}\text { Sig. (2- } \\
\text { tailed) }\end{array}$} \\
\hline & $\mathbf{N}$ & Mean & \begin{tabular}{|c|} 
Std. \\
Deviation
\end{tabular} & Mean & \begin{tabular}{|c|} 
Std. \\
Deviation
\end{tabular} & & & \\
\hline $\begin{array}{l}\text { Group-1(1 to } 5 \\
\text { year) }\end{array}$ & 119 & 6.26 & 1.048 & 11.12 & 2.02 & 4.86 & -23.49 & 0.00 \\
\hline $\begin{array}{l}\text { Group-2(6 to } \\
10 \text { year) }\end{array}$ & 28 & 6.07 & 1.30 & 10.54 & 1.93 & -4.46 & -0.71 & 0.00 \\
\hline $\begin{array}{l}\text { Group-3(11 to } \\
15 \text { year) }\end{array}$ & 3 & 4.89 & 0.42 & 10.76 & 1.18 & 5.87 & -6.3 & 0.00 \\
\hline Total & 150 & 6.20 & 1.10 & 11.01 & 2.00 & 4.81 & -26.20 & 0.00 \\
\hline
\end{tabular}

The mean cardiac output (resting) of cricket players of group-1 (1 to 5 year), group-2 (6 to 10 year) and group-3 (11 to 15 year) on the basis of their playing experience was $6.26 \pm 1.04(\mathrm{~L} / \mathrm{min})$, $6.07 \pm 1.30(\mathrm{~L} / \mathrm{min})$ and $4.89 \pm 0.42(\mathrm{~L} / \mathrm{min})$ respectively (Table 3$)$. The variance in the mean cardiac output (resting) of cricket players on the basis of playing experience was statistical analyzed with the help of ANOVA. The results of ANOVA showed that there was no statistical significant difference in the variance of group-1 (1 to 5year), group-2 (6 to 10 year) and group-3 (11 to 15 year) of cricket players (Table 4). The mean cardiac output (after Queen's step test) of cricket players on the basis of their playing experience was $11.12 \pm 2.02(\mathrm{~L} /$ beat $), 10.54 \pm 1.93(\mathrm{~L} / \mathrm{min})$ and $10.76 \pm 1.18(\mathrm{~L} / \mathrm{min})$ of group-1 (1 to 5 year), group-2 (6 to 10 year) and group-3 (11 to 15 year)respectively (Table 5). The variance in the cardiac output (after Queen's step test) of cricket players on the basis of playing experience was statistical analyzed with the help of ANOVA. The results of ANOVA showed that there was no statistical significant difference in the variance of mean cardiac output (after Queen's step test) of group-1 (1 to 5 year), group-2 (6 to 10 year) and group-3 (11 to 15 year) cricket players (Table 6). 
Journal of Exercise Science \& Physiotherapy Vol.17 No.1 (January to June) 2021

ISSN: 0973-2020 (Print) I2OR Impact Factor =7.005 ISSN: 2454-6089 (Online)

Table 3. Comparison of Cardiac output (resting) of Cricket Players

\begin{tabular}{|l|l|c|c|c|}
\hline Variable(s) & Player's Playing Experience & N & Mean & Std. Deviation \\
\hline \multirow{3}{*}{$\begin{array}{l}\text { Cardiac Output (resting) } \\
\text { (L/min) }\end{array}$} & Group-1(1 to 5 year) & 119 & 6.26 & 1.048 \\
\cline { 2 - 5 } & Group-2(6 to 10 year) & 28 & 6.07 & 1.30 \\
\cline { 2 - 5 } & Group-3(11 to 15 year) & 3 & 4.89 & 0.42 \\
\cline { 2 - 5 } & Total & 150 & 6.20 & 1.10 \\
\hline
\end{tabular}

Table.4 Analysis of Variance (ANOVA) of Cardiac output (resting) of Cricket Players

\begin{tabular}{|l|l|c|c|c|c|c|}
\hline Variable(s) & & Sum of Squares & df & Mean Square & F & Sig. \\
\hline $\begin{array}{l}\text { Cardiac Output (resting) } \\
\text { (L/min) }\end{array}$ & Between Groups & 5.97 & 2 & 2.98 & 2.49 & 0.08 \\
\cline { 2 - 7 } & Within Groups & 176.29 & 147 & 1.19 & & \\
\cline { 2 - 7 } & Total & 182.27 & 149 & & & \\
\hline
\end{tabular}

Table.5 Comparison of Cardiac output (after Queen's step test) of Cricket

\begin{tabular}{|l|l|c|c|c|}
\hline Variable(s) & $\begin{array}{l}\text { Player's Playing } \\
\text { Experience }\end{array}$ & N & Mean & $\begin{array}{c}\text { Std. } \\
\text { Deviation }\end{array}$ \\
\hline $\begin{array}{l}\text { Cardiac Output } \\
\text { (after Queen's step test) }\end{array}$ & Group-1(1 to 5 year) & 119 & 11.12 & 2.02 \\
\cline { 2 - 5 } & Group-2(6 to 10 year) & 28 & 10.54 & 1.93 \\
\cline { 2 - 5 } & Group-3(11 to 15 year) & 3 & 10.76 & 1.18 \\
\cline { 2 - 5 } & Total & 150 & 11.01 & 2.00 \\
\hline
\end{tabular}

Table.6 Analysis of Variance (ANOVA) of Cardiac output (after Queen's step test) of Cricket Players

\begin{tabular}{|l|l|c|c|c|c|c|}
\hline Variable(s) & & Sum of Squares & df & Mean Square & F & Sig. \\
\hline $\begin{array}{l}\text { Cardiac Output } \\
\text { (after Queen's step test) }\end{array}$ & Between Groups & 7.96 & 2 & 3.98 & 0.99 & 0.37 \\
\cline { 2 - 7 } & Within Groups & 588.77 & 147 & 4.00 & & \\
\cline { 2 - 7 } & Total & 596.73 & 149 & & & \\
\hline
\end{tabular}

\section{Discussion}

The results of the present study shows that cardiac output (at rest) of the cricket players were in the normal range $(4.0-8.0 \mathrm{~L} / \mathrm{min})$ as per the norms recommended by Edwards's Life Sciences (Edwards, 2009). Rowell (1986) reported that the pattern of blood flow changes dramatically when a person goes from resting to exercising. At rest, the skin and skeletal muscles receive about 20 percent of the cardiac output. Especially during an intensive workout, more blood and oxygen are required to the peripheral tissues of the arms and legs in highly trained cricketer bodies. A larger heart results in higher cardiac output, which also allows it to beat more slowly, as more blood is pumped out with each beat (Hargreaves 2020).That's likely because exercise strengthens the heart muscle. It allows it to pump a greater amount of blood with each heartbeat. It results in better oxygen supply to the muscles resulting in lesser heart rate as compared to the non- cricketer 


\section{Journal of Exercise Science \& Physiotherapy Vol.17 No.1 (January to June) 2021 \\ ISSN: 0973-2020 (Print) I2OR Impact Factor =7.005 ISSN: 2454-6089 (Online)}

(King \& Wood 2013). It was observed in the present study that the cardiac output was significantly increased after step test than at rest of cricket players of groups. A similar results were also observed by Kathayat \& Kumar (2020) in the variance of mean cardiac output (after Queen's step test) of national level, state level, district level, university level and school level cricket players. Exercise-induced increases in cardiac size were initially identified in the late 1890s, (Weiner \& Baggish, 2014 and Darling 1899) and they were first described in the 1950s (Beckner 1954). This form of cardiac hypertrophy occurs primarily in highly trained athletes, is relatively mild $(\approx 10 \%-$ $20 \%$ increase in heart mass), and is reversible on prolonged cessation of exercise (Maillet et al., 2013). It is accompanied by unchanged or marginally enhanced systolic and diastolic function (DeMariaet al. 1978). Regular exercises that promote sustained increases in cardiac output (e.g. endurance running) cause an eccentric form of cardiac remodeling, whereas exercises that increase systemic arterial pressures (e.g. weight lifting) often promote concentric hypertrophy (Pluimet al. 1998 and Pluimet al. 2000). Although adaptation of the heart to exercise is generally beneficialprotecting the heart from ischemia-reperfusion injury (Burelle et al. 2004; Calvert et al. 2011) and increasing stroke volume (Platt et al., 2015). The cricketer Cardiac intermediary metabolism in exercise an acute increase in workload during exercise has robust effects on the metabolism of striated muscle (Gibala et al. 2006). In the heart, exercise increases contractile power and oxygen consumption up to 10-fold above resting rates (Saugel et al. 2015, Lopaschuk et al. 2010). Changes in substrate utilization and ATP production during exercise are a product of the integrated effects of physiologic cues that occur with changes in circulating hormones, metabolic substrates, and hemodynamics (Gibala et al. 1998). Although intermittent bouts of strenuous physical activity are known to elicit adaptive changes in skeletal muscle gene expression, (Egan and Zierath 2013) less is known about how exercise impacts gene expression in the heart. Decreases in glucose catabolism occurring in the later stages of relatively vigorous exercise (Gibb et al. 2017) seem to be important for expression of genes that promote physiological cardiac growth. Metabolic changes caused by exercise are important for cardiac remodeling and adaptation. The integrative metabolic changes brought forth by exercise combine with changes in cardiac workload to regulate cardiac metabolism. In particular, exercise alters levels of competing substrates, and it changes the abundance of circulating hormones, which cue metabolic pathways that are critical for transcriptional changes and cardiac growth. In addition, changes in circulating and endogenous metabolites can trigger physiologic growth by activating pro-hypertrophic signaling pathways. Nevertheless, numerous questions remain, including questions of how to optimize the amount of exercise to produce beneficial, as opposed to deleterious, effects on cardiovascular health (Kim and Baggish, 2016) as well as mechanistic questions of how exercise-induced changes in metabolism couple the synthesis of structural materials to activation of the physiological cardiac growth program (Gibb and Hill 2018). While this knowledge is acquired, it appears that we would be best served by sticking to the advice of the ancient Greeks-"Exercise till the mind feels delight in reposing from the fatigue."- Socrates. The cardiac output increases as the rate of oxygen demand increases. However, this linear relationship has a certain limit after which the cardiac output stays constant. The heart rate increases as the oxygen demand increases in order to maintain a constant cardiac output. When a person is at rest, only $20 \%$ of the cardiac output goes to the skin and the skeletal muscles. However, when they are exercising, more blood needs to flow toward the highly metabolic skeletal muscles (Kathayat and Kumar 2019). This is to allow the provision of more oxygen and removal of waste products such as carbon dioxide. It is estimated that up to $80 \%$ of the cardiac output is supplied to the skeletal muscles and the skin in exercise (Lecturio, 2016).

\section{Conclusion}

It was concluded that the cardiac output was statistical significantly increased after step test than at rest of cricket players of different playing experience. There was a statistical significant difference 


\section{Journal of Exercise Science \& Physiotherapy Vol.17 No.1 (January to June) 2021 \\ ISSN: 0973-2020 (Print) I2OR Impact Factor =7.005 ISSN: 2454-6089 (Online)}

in the variance of mean cardiac output (after Queen's step test) of 1 to 5 year, playing experience of 6 to 10 year, playing experience of 11 to 15 year) cricket players.

\section{Acknowledgment}

The authors thank all the subjects who voluntarily participated in this study from Govt. Multi-Purpose Secondary School Patiala, Cricket Hub Academy Patiala, Master Cricket Class Academy Patiala, Budda Dal Sports Complex Patiala, DMW Cricket Academy Patiala and Black Elephant Cricket Club Patiala and all other Cricket Academies situated at Patiala, Punjab.

\section{References}

Adikali KabaSesay 1, Alpha BassieMansarayJavedSoomro Ali. 2017. Exercise and Its Corresponding Effect on Cardiac Output. International Journal of Scientific and Research Publications, Volume 7, pp 546-555.

Beckner GL, Winsor T. 1954. Cardiovascular adaptations to prolonged physical effort. Circulation. 9:835846.

Bergman BC, Tsvetkova T, Lowes B, Wolfel EE.2009. Myocardial FFA metabolism during rest and atrial pacing in humans. Am J PhysiolEndocrinolMetab. 296:E358-E366.

Bergman BC, Tsvetkova T, Lowes B, Wolfel EE.2009. Myocardial glucose and lactate metabolism during rest and atrial pacing in humans. J Physiol.587:2087-2099.

Burelle Y, Wambolt RB, Grist M, Parsons HL, Chow JC, Antler C, Bonen A, Keller A, Dunaway GA, Popov KM, Hochachka PW, Allard MF(2004). Regular exercise is associated with a protective metabolic phenotype in the rat heart. Am J Physiol Heart Circ Physiol. 287:H1055-H1063.

Busseuil D, Shi Y, Mecteau M, Brand G, Gillis MA.2010. Heart rate reduction by ivabradine reduces diastolic dysfunction and cardiac fibrosis. Cardiology 117: 234-242.

Calvert JW, Condit ME, Aragon JP, Nicholson CK, Moody BF, Hood RL, Sindler AL, Gundewar S, Seals DR, Barouch LA, Lefer DJ.2011. Exercise protects against myocardial ischemia-reperfusion injury via stimulation of $\beta(3)$-adrenergic receptors and increased nitric oxide signaling: role of nitrite and nitrosothiols. Circ Res.108:1448-1458.

Darling EA.1899. The effects of training. A study of the Harvard University crews. Boston Med Surg J.CXLI:229-233.

DeMaria AN, Neumann A, Lee G, Fowler W, Mason DT.1978. Alterations inbventricular mass and performance induced by exercise training in manbevaluated by echocardiography. Circulation. 57:237-244.

Duning T, Kirchhof P, Wersching H, Hepp T, Reinhardt R, et al. 2011. Extended Electrocardiographic Poincare Analysis (EPA) for Better Identification of Patients with Paroxysmal Atrial Fibrillation. $J$ Clinic Experiment Cardiol 2: 123.

Edward life sciences LLC (2009). www.edwards.com

Egan B, and Zierath JR.2013. Exercise metabolism and the molecular regulation of skeletal muscle adaptation. Cell Metab. 17:162-184. doi: 10.1016/j.cmet.2012.12.012.

Gibala, M. J., Little, J. P., Van Essen, M., Wilkin, G. P., Burgomaster, K. A., Safdar, A.,...Tarnopolsky, M. A. (2006). Short-term sprint interval versus traditional endurance training: similar initial adaptations in human skeletal muscle and exercise performance. The Journal of Physiology, 575(3), 901-911.

Gibb AA, Epstein PN, Uchida S, Zheng Y, McNally LA, Obal D, Katragadda K, Trainor P, Conklin DJ, Brittian KR, Tseng MT, Wang J, Jones SP, Bhatnagar A, Hill BG.2017. Exercise-induced changes in glucose metabolism promote physiological cardiac growth. Circulation. 136:2144-2157.

Gibb, A., \& Hill, B. G.2018. Metabolic Coordination of Physiological and Pathological Cardiac Remodeling. https://www.researchgate.net/publication/325919335_Metabolic_Coordination_of_Physiological_an d_Pathological_Cardiac_Remodeling.page 107-128.

Goodwin GW, and Taegtmeyer H 2000. Improved energy homeostasis of the heart in the metabolic state of exercise. Am J Physiol Heart Circ Physiol. 279:H1490-H1501.

Hargreaves, M., \&Spriet, L. L. 2020. Skeletal muscle energy metabolism during exercise. Nature Metabolism, 2.

Hussien M, Refaat E, Fayed N, Yassen K, Khalil M, et al.2011. Use of transesophageal Doppler as a sole cardiac output monitor for reperfusion hemodynamic changes during living donor liver transplantation: An observational study. Saudi J Anaesth 5: 264-269. 


\section{Journal of Exercise Science \& Physiotherapy Vol.17 No.1 (January to June) 2021 \\ ISSN: 0973-2020 (Print) I2OR Impact Factor =7.005 ISSN: 2454-6089 (Online)}

Jackson, C. E. 1955. Nomogram for simple calculation of cardiac output. Circulation 11: 635.

Kathayat, L. B., \& Kumar, A. (2019). Comparison of Cardiac Output of Cricket Players before and after Step Test according to their Playing Positions. Journal of Exercise Science and Physiotherapy, 15(1) 1014.

Kathayat, L. B., \& Kumar, A. (2020). Comparison of Cardiac output of Cricket Players of different Level of Participation before and after Step Test. Journal of Exercise Science and Physiotherapy, 16(2) 3237.

Kim, J. H., \& Baggish, A. L.2016. Physical Activity, Endurance Exercise, and Excess-Can One Overdose? Current Treatment Options in Cardiovascular Medicine.vol.18.

King, G., \& Wood, M. J.2013. The Heart of the Endurance Athlete Assessed by Echocardiography and Its Modalities: "Embracing the Delicate Balance." Current Cardiology Reports, 15(8). https://doi.org/10.1007/s11886-013-0383-1.

Kirolos, I., Yakoub, D., Pendola, F., Picado, O., Kirolos, A., Levine, Y. C., Khouzam, R. N. 2019. Cardiac physiology in post myocardial infarction patients: the effect of cardiac rehabilitation programs-a systematic review and update meta-analysis. Annals of Translational Medicine, 7(17), 416-416.

Lecturio. (2016). Cardiovascular Response to Exercise. Online Medical Library.

Maillet M, van Berlo JH, Molkentin JD (2013). Molecular basis of physiological heart growth: fundamental concepts and new players. Nat Rev Mol Cell Biol. 14:38-48..

Platt C, Houstis N, Rosenzweig A.2015. Using exercise to measure and modify cardiac function. Cell Metab. 21:227-236.

Pluim BM, Lamb HJ, Kayser HW, Leujes F, Beyerbacht HP, Zwinderman AH, van der Laarse A, Vliegen HW, de Roos A, van der Wall EE.1998. Functional and metabolic evaluation of the athlete's heart by magnetic resonance imaging and dobutamine stress magnetic resonance spectroscopy. Circulation. 97:666-672.

Pluim BM, Zwinderman AH, van der Laarse A, van der Wall EE.2000. The athlete's heart. A meta-analysis of cardiac structure and function. Circulation. 101:336-344.

Rowell, L. B.1986. Human Circulation: Regulation During Physical Stress. New York: Oxford University Press.

Takahashi, K., Kakimoto, Y., Toda, K., \& Naruse, K.2013. Mechanobiology in cardiac physiology and diseases. Journal of Cellular and Molecular Medicine, 17(2), 225-232.

Weiner, R. B., \& Baggish, A. L. 2014. Acute versus chronic exercise-induced left-ventricular remodeling. Expert Review of Cardiovascular Therapy, 12(11), 1243-1246.

Xing, C.-Y., Tarumi, T., Liu, J., Zhang, Y., Turner, M., Riley, J., Zhang, R. 2016. Distribution of cardiac output to the brain across the adult lifespan. Journal of Cerebral Blood Flow \& Metabolism, 37(8), 2848-2856.

Zhang He SR;C;Liu YM;Sun YX;Zhuang J;Chen JM;Madigan VM;Smith BE;Sun X.2011. Accuracy of the ultrasonic cardiac output monitor in healthy term neonates during postnatal circulatory adaptation. Chinese Medical Journal, 124(15).

Conflict of Interest: None declared 